OPEN ACCESS

Edited by:

Samar Damiati,

Royal Institute of Technology, Sweden

Reviewed by:

Tim Sandle,

The University of Manchester, United Kingdom

Showkat Ganie,

Royal Holloway University of London, United Kingdom

*Correspondence:

Rania El-Tanbouly

ran.eltanbouly@alexu.edu.eg

Sarah El-Messeiry

sarah.elmesseiry@alexu.edu.eg

tORCID:

Rania El-Tanbouly

orcid.org/0000-0002-8933-1601

Ziad Hassan

orcid.org/0000-0003-3301-4567

Sarah El-Messeiry

orcid.org/0000-0002-3115-5625

${ }^{\text {F}}$ These authors have contributed equally to this work

Specialty section:

This article was submitted to

Molecular Diagnostics and

Therapeutics,

a section of the journal

Frontiers in Molecular Biosciences

Received: 13 May 2021 Accepted: 18 June 2021

Published: 30 June 2021

Citation:

El-Tanbouly R, Hassan Z and El-Messeiry S (2021) The Role of Indoor Plants in air Purification and

Human Health in the Context of COVID-19 Pandemic: A Proposal for a

Novel Line of Inquiry.

Front. Mol. Biosci. 8:709395. doi: 10.3389/fmolb.2021.709395
The Role of Indoor Plants in air Purification and Human Health in the Context of COVID-19 Pandemic: A Proposal for a Novel Line of Inquiry

\author{
Rania El-Tanbouly ${ }^{1 * t \neq}$, Ziad Hassan ${ }^{2 \dagger}$ and Sarah El-Messeiry ${ }^{2 * t \neq}$ \\ ${ }^{1}$ Department of Floriculture, Ornamental Horticulture and Landscape Design, Faculty of Agriculture, Alexandria University, \\ Alexandria, Egypt, ${ }^{2}$ Department of Genetics, Faculty of Agriculture, Alexandria University, Alexandria, Egypt
}

The last two decades have seen the discovery of novel retroviruses that have resulted in severe negative consequences for human health. In late 2019, severe acute respiratory syndrome coronavirus 2 (SARS-CoV-2) emerged with a high transmission rate and severe effects on human health, with $5 \%$ infected persons requiring hospitalisation and 3.81 million deaths to date globally. Aerosol particles containing virions are considered the main source of SARS CoV-2 transmission in this pandemic, with increased infection rates in confined spaces. Consequently, public and private institutions had to institute mitigation measures including the use of facial masks and social distancing to limit the spread of the virus. Moreover, the role of air purification and bio-decontamination is understood as being essential to mitigate viral spread. Various techniques can be applied to bio-decontaminate the air such as the use of filtration and radiation; however, these methods are expensive and not feasible for home use. Another method of air purification is where indoor plants can purify the air by the removal of air pollutants and habituated airborne microbes. The use of indoor plants could prove to be a cost-efficient way of indoor air-purification that could be adapted for a variety of environments with no need for special requirements and can also add an aesthetic value that can have an indirect impact on human health. In this review, we discuss the emergence of the COVID-19 pandemic and the currently used air purification methods, and we propose the use of indoor plants as a new possible eco-friendly tool for indoor air purification and for reducing the spread of COVID-19 in confined places.

Keywords: COVID-19, SARS-CoV-2, indoor plants, air-purification, phytoremediation, humidity, human health

\section{THE EMERGENCE OF THE COVID-19 PANDEMIC}

Viruses are small-sized infectious organisms that can be divided into classes according to the type of their genetic material. Retroviruses are a family of viruses in which the ribonucleic acid (RNA) encodes all their genetic information; this family includes severe acute respiratory syndrome coronavirus 2 (SARS-CoV-2), which results in coronavirus disease-2019 (COVID-19) (Petrosillo et al., 2020). Retroviruses possess the ability to invade and infect the host somatic cells and integrate their genetic information into the host genome as a double-strand deoxyribonucleic acid (DNA) (MacLachlan et al., 2017). This process is done using a reverse transcriptase enzyme which can convert their RNA genetic material into DNA inside the host cells via a complementary DNA (cDNA) intermediate (Johnson 2019; Martín-Alonso et al., 2021). The retroviruses family shares a 


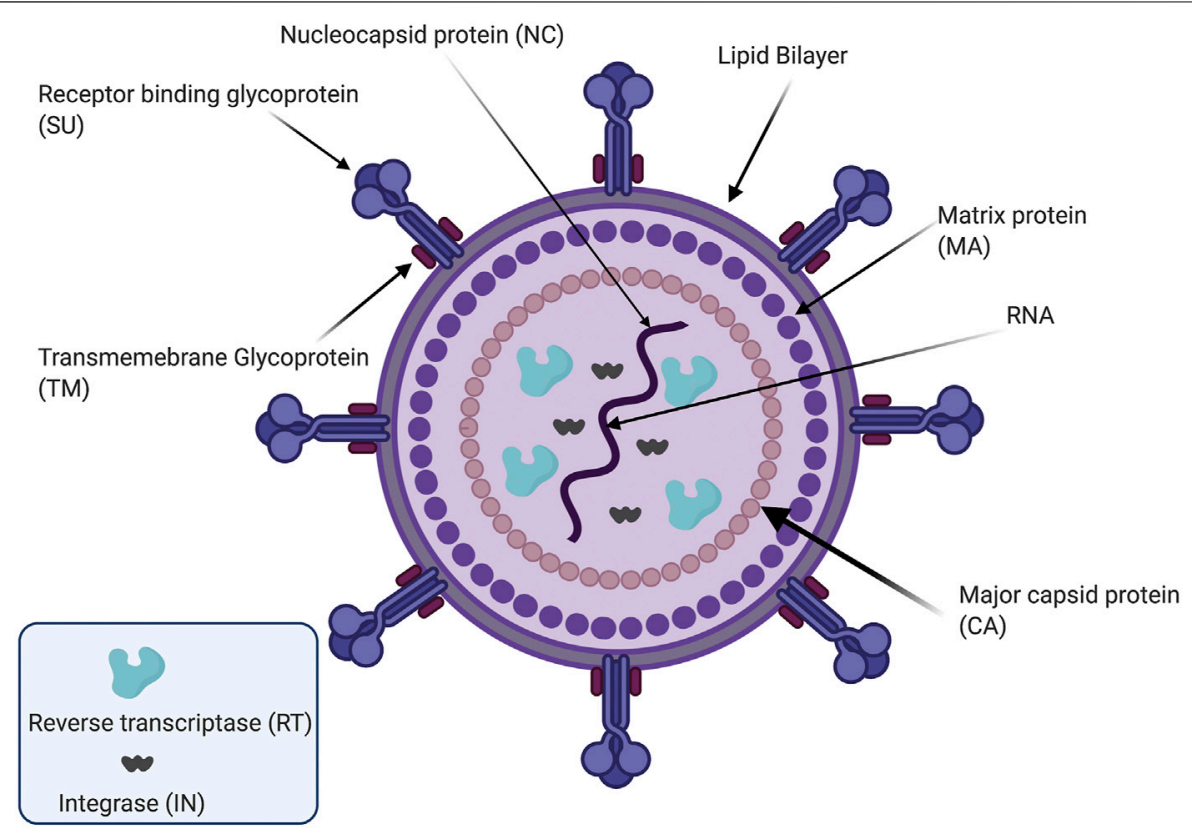

FIGURE 1 | A schematic drawing illustrating the structure of retrovirus. The virus is surrounded by a lipid bilayer membrane. The membrane contains the transmembrane (TM) region and receptor binding glycoprotein (SU). The viral matrix protein (MA) covers the internal side of the viral membrane, while the capsid protein (CA) covers the viral core. The viral core is composed of the viral RNA in addition to the nucleocapsid (NC) protein. The viral core also contains viral replicating enzymes integrase $(\mathrm{IN})$, and reverse transcriptase (RT). This figure is created by BioRender software.

standard structure including an outside envelope with a unique spike protein, which aids in the infection process for each virus, and a single positive strand of RNA that encodes the genetic material including the promoter and regulatory elements essential for the transcription of the viral RNA (Figure 1) (Zhang et al., 2015; Dhama, 2020; Kim et al., 2020; Lu et al., 2020).

Retrovirus family members exhibit a higher mutational rate compared to other viruses of $(4.1 \pm 1.7) \times 10^{-3}$ per base per cell due to the nature of their genetic information. This mutational activity results in a higher adaptation rate and an increasing number of viruses being discovered every year (Cuevas et al., 2015).

Humankind has been exposed to many pandemic outbreaks that have affected several societies and populations throughout history. However, scientific communities have aided in finding a solution and understanding the source of the pandemic during these harsh times (History 2019). The first pandemic in the 21st century was caused by a member of the coronaviruses family called severe acute respiratory syndrome (SARS), which was discovered in China in 2002 (Cherry and Krogstad 2004). This was preceded in 2012 by an epidemic caused by another member of the same family, the Middle East respiratory syndrome coronavirus (MERS-CoV), first identified in the Kingdom of Saudi Arabia (K.S.A.) after a citizen was admitted to the hospital exhibiting symptoms of severe pneumonia (Fehr et al., 2017). In February 2020, the world was shaken by the WHO announcement of a new pandemic first discovered in China from the same family called SARS-CoV-2 (Brooks et al., 2020; Harapan et al., 2020). This virus was more transmissible than others in the same family as it had a high infection rate of a basic reproductive number $\mathrm{R}_{0}=3.1$ (Billah et al., 2020; Liu Y., et al., 2020; Read et al., 2020), and a death rate of around 10\% (Li et al., 2019). SARS-CoV-2 was shown to be transmitted via horizontal methods including direct contact, droplets, and erosols, or by vertical methods such as surgical procedures and pregnancy (Belser, Rota, and Tumpey 2013; Jiang et al., 2020; Rahman et al., 2020).

A month after the first COVID-19 announcement, the WHO declared the disease outbreak as a global pandemic (Ullah et al., 2020). The SARS-CoV-2 virus has caused threats to public health and resulted in a global travel shutdown all over the world, causing deaths that reached 2,271,180 and confirmed cases 104,370,550 (WHO 6-2-2021) (Liu et al., 2020a). However, current cures and treatments remain insufficiently effective (Liu Q., et al., 2020). Vaccines remain our first line of worldwide virus eradication, and they are limited by storage life and global availability. Hence, governments have applied drastic measures in their countries and required infected persons to be isolated at home, with only severe cases being hospitalized (Kumar and Khodor, 2020; McAleer 2020; Ullah et al., 2020; Vellingiri et al., 2020).

\section{OVERVIEW ON THE SARS-COV-2 VIRUS}

The SARS-CoV-2 virus belongs to a monogenic retrovirus family called coronaviridae (CoV) (Sturman and Holmes 1983), whose members can infect up to 200 different hosts (Kasmi et al., 2019). Viruses belonging to this family are spherical, enveloped, and contain a positive-sense, single-stranded RNA (Holmes 1999; Ii 
et al., 2005; Payne 2017). The coronaviridae family is composed of two subfamilies; torovirinae and coronavirinae; the latter has four genera (Kasmi et al., 2019). SARS-CoV-2 was shown genetically to belong to the genus Betacoronavirus along with other coronavirinae respiratory viruses (SARS and MERS). SARS and MERS have infected people worldwide in the last 2 decades with patients exhibiting common cold symptoms resulting in the virus affecting the human respiratory system severely within days of the infection (Li et al., 2019). These two viruses have resulted in the loss of lives in the last 2 decades with a fatality rate of 9.5 and $34.4 \%$, respectively. Studies have shown that SARS-CoV-2 is genetically similar to SARS and MERS, however, the fatality rate of the virus was lower than both viruses with around $2.3 \%$. The reduced severity of the CoV-2 virus contributed to a much higher infection rate $\left(\mathrm{R}_{0}=2-2.5\right)$ than the SARS $\left(\mathrm{R}_{0}=1.7-1.9\right)$ and the MERS $\left(\mathrm{R}_{0}=>1\right)$ viruses (Petrosillo et al., 2020), which means that the virus can stay for a long time in the air, increasing the need for air purification as a mitigation method. SARS-CoV-2 has a diameter of $(60-15 \mathrm{~nm})$ with a viral genome code for sixteen non-structural proteins (Nsps), in addition to four structural proteins including the $180-200 \mathrm{KDa}$ spike protein (S) which is responsible for the viral subtyping and infection (Gordon et al., 2020; Huang et al., 2020; Kim et al., 2020; Zhu et al., 2020). SARS-CoV-2 has shown genomic and phylogenetic similarity of $75-85 \%$ with SARS-CoV (Abdelrahman et al., 2020; Hu et al., 2020; Uddin et al., 2020), especially in the $S$ gene and receptor-binding domain (RBD) (Andersen et al., 2020; Zhou et al., 2020). The glycoprotein spikes on the outer surface of coronaviruses are responsible for the attachment and entry of the virus to host cells (Shereen et al., 2020), as they bind to the Angiotensin-converting enzyme 2 (ACE2) receptor, that is expressed in many body organs such as lungs, kidney, heart and gastrointestinal tract (Hamming et al., 2004; Tikellis and Thomas 2012; Roca-Ho et al., 2017; Davidson et al., 2020; Samavati and Uhal 2020). This is mediated by the binding domain of the protein (Tai et al., 2020); this is then followed by fusion of viral membrane (Walls et al., 2020), which will subsequently release its genetic material in the cytoplasm of the host to be translated (Astuti 2020).

Primarily respiratory disease transmission occurs within 5-6 days of the infection, COVID-19 patients show symptoms that vary from dry cough, fever, breathing difficulties, fatigue, headache, diarrhea, sore throat to severe pneumonia, which increase the need for biodecontamination (Hosseini et al., 2020). Due to the high mutation rate of the virus, new variants of the SARS-CoV-2 virus are being discovered and named according to the countries in which the virus has been discovered such as (United Kingdom, Brazil, South Africa, and recently in India), complicating viral containment efforts (Callaway 2020; Jia et al., 2020; Korber et al., 2020; Desai et al., 2021; Zhou et al., 2021).

Molecular methods such as the use of real-time polymerase chain reaction (RT-PCR) to detect the virus genome are considered the standard methods in the diagnosis of this disease. Other rapid detection methods are also used to detect the presence/absence of the antibodies produced by the immune system upon infection; this method is considered as the most expensive and time effective. New diagnostic methods are being developed every day to enhance the detection specificity and accuracy and to aid in restricting the virus spread via early and easy diagnosis among with the population (Islam and Iqbal 2020).

\section{THE ROLE OF AIR PURIFICATION IN FIGHTING THE COVID-19 SPREAD}

The SARS-CoV-2 virus has been shown to spread via three main routes; erosols, which are relatively small airborne microdroplets $(1-4 \mu \mathrm{m})$, large respiratory droplets $(>5 \mu \mathrm{m})$, and close contact with infected surfaces and people. The latter two sources of transmission can be handled via disinfection of surfaces and the use of proper protective equipment. Small erosols droplets, however, are harder to contain with standard sterilization methods and are considered to be the main source of spread, with reports of virion-containing droplets being able to travel in the air and remain viable for around $3 \mathrm{~h}$ (Pagliano and Kafil 2020). Most respiratory infections are transmitted via respiratory droplets larger than $5 \mu \mathrm{m}$ when coughing and sneezing, that are then deposited onto surfaces (Siegel et al., 2019). Pathogens suspended in erosol particles smaller than $5 \mu \mathrm{m}$ can remain airborne and can deposit in the lower respiratory tract, while those in particles with size ranging from 6-12 $\mu \mathrm{m}$ are deposited in the upper respiratory tract (Brown et al., 1950; Harper and Morton, 1953; Fennelly 2020). Many studies have showed that pathogens and viruses can be found in small particles less than $5 \mu \mathrm{m}$ (Stelzer-Braid et al., 2016). A recent study was able to detect viral presence in hospital air samples in isolation rooms via RTPCR, with detected virions in particles with a size range of $1-4 \mu \mathrm{m}$ and $>4 \mu \mathrm{m}$ (Liu et al., 2020b; Chan et al., 2020; Karia et al., 2020; Rahman et al., 2020). Another study revealed that more than $60 \%$ of the air samples from COVID-19 patient rooms contained the virus (Santarpia et al., 2020).

For all the above reasons, critical mitigation measures were put in place to control the spread and control the transmission rate of COVID-19, including closure of high-traffic institutions such as schools and universities, instituting social distancing to decrease exposure to respiratory droplets with COVID-19; use of facial masks to cover nose and mouth, especially when physical distancing cannot be achieved (as in shared transport); reducing the number of workers per square unit; and enhanced ventilation, air filtration, and conditioning to reduce the number of virus-containing droplets and microdroplets in a given environment. Further mitigation measure included advising sick individuals to stay home to avoid potentially infecting others, liberal use of hand-washing and alcohol containing sanitizing gels, and covid-testing where available to identify individuals infected with COVID and potentially infected close contacts (Health et al., 2020; Sandle 2020; Bazant and John, 2021). Additional measures were also needed in institutions to ensure a pathogenic-free environment such as surface cleaning and air purification (Sandle 2021). Many traditional methods were employed to filter the air, additionally, several companies are using artificial intelligence and mechanized systems to biodecontaminate and clean the area in a time-cost efficient manner (Luengas et al., 2015; Ethington et al., 2018; Garfin 2020; Menut et al., 
TABLE 1 | a comparison between the most common methods of air filtration and purification that are used to fight bacteria, fungi and virus spread.

\begin{tabular}{|c|c|}
\hline & HEPA filters \\
\hline $\begin{array}{l}\text { Mode of } \\
\text { action and }\end{array}$ & $\begin{array}{l}\text { It functions by the combination of three aspects. First, outer filters that work like } \\
\text { sieves to stop the larger particles of dirt }\end{array}$ \\
\hline
\end{tabular}

properties

A concertina filter-a mat of very dense fibers-forms the middle layer which traps smaller particles. These are designed to remove $90 \%$ of particles from the air. The inner part catch particles as they pass through in the moving air

Different grades of HEPA filters differ in their 'efficiency ratings'. The most used HEPA filter is the $\mathrm{H} 14$ filter, which is designed to eliminate $99.997 \%$ of particles from the air Sandle (2013)

The performance of the HEPA filter system depends on its setting and position. Nevertheless, the use of a mobile HEPA filter system seems a good alternative to use when no ventilation options are available Bluyssen et al. (2021)

Efficiency Commercial HEPA filters (99.95\%) retain more than $9.996 \%$ of Titanium dioxide $\left(\mathrm{TiO}_{2}\right)$-coated HEPA filters were shown to be able to actinophage particles Roelants et al. remove $60-80 \%$ of airborne spore(1968), Dee et al. (2006), Christopherson et al. (2020) forming bacteria and fungi

Chuaybamroong et al. (2010)

\section{UV radiation}

Air disinfection using 254 nm UV-C is an effective tool for inactivating viral erosols. Air microbes, genetic material and protein absorption the UV light resulting in severe cellular damage to the organism Walker and Ko (2007)

Air cleaners alone or combined with upper-room air Ultraviolet germicidal irradiation (UVGI) can purify the air by removing bioaerosols at significant rates in high-exposure environments such as hospitals, correction facilities Kujundzic et al. (2006)
Ionization

It can prevent transmission of airborne viral infections. The ionization device consists of a small portable ionizer, where a sampling cup of positive charge is attached to the ionizer attracting negative particles from the air

Higher numbers of viral particles detected on the active ionizer compared to the inactive ionizer led to the conclusion that this technique can efficiently capture and collect viral particles from the air Hagbom et al. (2015)
Exposing viral particles to UV-C for $1 \mathrm{~s}$ is lethal and possesses the potential to inactivate the viral particles Sabino et al. (2020)
Air ionizers are capable of purifying the air of fine and ultra-fine particles with high efficiency Grabarczyk (2001), Uk Lee et al. (2004), Shiue et al. (2011), Pushpawela et al. (2017)
2020; Muhammad, Long, and Salman 2020; Mukhtar et al., 2020; Megahed and Ghoneim 2021). Researchers also implemented a highly sensitive camera to monitor microdroplets that may transmit viruses providing data that enabled organizations and scientists to guide people on how to protect themselves against disease transmission (Noti et al., 2013).

Practices such as good air ventilation, avoidance of air recirculation, minimization of the number of people in indoor areas and air filtration techniques have been proven to aid in the reduction of the virus spread (Morawska et al., 2020). Filtering the air from virion-containing erosols is especially important in hospitals and COVID treatment units. This can be done by the use of filters such as high-efficiency particle arrestance (HEPA) filters, the highest class of which can trap erosol particles of $0.3 \mu \mathrm{m}$ diameter with $99.97 \%$ efficacy according to (ISO 29463-1:2011, 2017; Nazarenko 2021) (Nazarenko 2021). While effective such units are impractical in most private residences and small-scale commercial shops due to the high cost of units needed to filter air in large open spaces. Ionization devices can also be used to clear the air from virion-containing droplets. Hagbom et al. have shown that ionizing devices clear influenza viruses from the air, trapping the virion-containing particles by creating negative ions that collide with particles of a size range of $35 \mathrm{~nm}$ to $10 \mu \mathrm{m}$. There results showed that the ionizer device prevented the infection spread with high efficacy in pigs (Hagbom et al., 2015). Also, Suwardi and colleges demonstrated that plant-based ionizers can aid in reduction of erosol-containing virions indoors (Suwardi et al., 2021). However, the wide use and potency of these air ionizing techniques are still not fully investigated. Air biodecontamination via Ultraviolet (UV) radiation is another method that can be applied to clear the air and surfaces for SARS-CoV-2 virions. UV-C light (200-280 nm) has the ability to damage viral RNA and proteins of the SARS-CoV-2 virus in liquid, solid, and air media (Raeiszadeh and Adeli 2020). The use of this method of air bio-decontamination is limited due to human safety concerns, thereby restricting the use of this method. Also, negative pressure air flow in hospital wards and rooms were shown to reduce the SARS-CoV-2 airborne presence (Pagliano and Kafil 2020). Table 1 summarizes the use of air filtration, UV sterilization and ionization techniques to filter and clear the air of bacteria, fungi, and viruses.

While the previously mentioned air purification and filtration methods are considered effective, there are some drawbacks that limit their widespread use in homes, schools, supermarkets, and small organisations. Indoor plants can be used as an unconventional method to clear the air from biological and non-biological contaminates as an environmental, and costand user-friendly alternative.

\section{THE ROLE OF PLANTS IN AIR PURIFICATION}

Plants are used as an efficient cleaning system for the environment in a process known as "Phytoremediation", which can be done via various techniques in which plants clear the environment from pollutants (Figure 2) (Pilon-Smits 


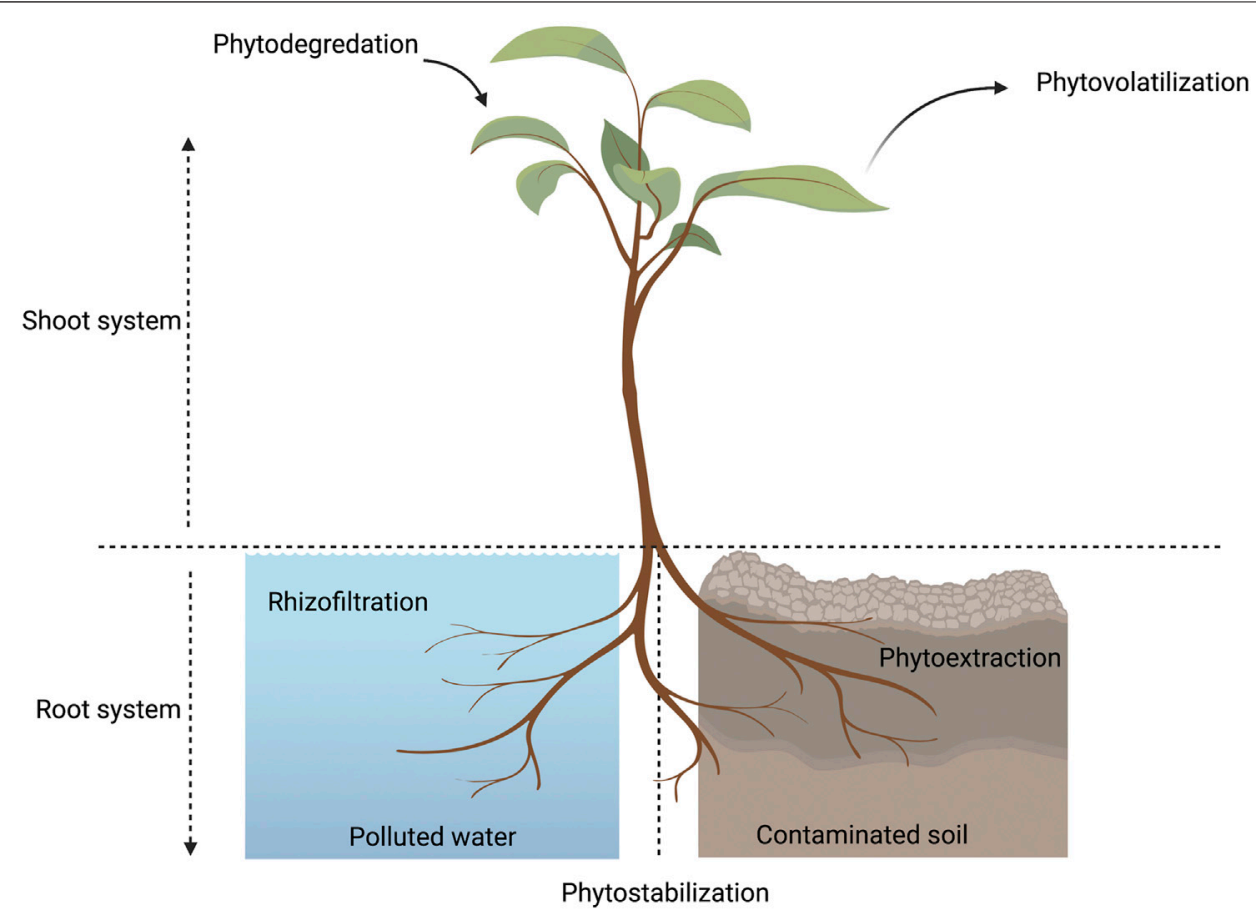

FIGURE 2 | A diagram showing the different phytoremediation techniques used by plants in different environments. Phytoremediation techniques are divided into five main areas. 1) Phyto-stabilization is immobilization of contaminants and pollutants in the soil, consequently reducing their bioavailability and decreasing the risk of leaching into water or spreading in air (Morikawa and Erkin 2003). 2) Phytoextraction is carried out by pollutant accumulation in plants (Lee 2013), 3) Phytodegradationis is the conversion of toxic pollutants into less harmful and non-toxic materials (Cunningham et al., 1995; Newman et al., 1997; Lee 2013), 4) Rhizo-filtration (Phytofiltration) involves either plant roots (rhizofiltration) or plant shoots (caulofiltration) or seedlings (blastofiltration) eliminating pollutants from water or wastewater (MesjaszPrzybyłowicz et al., 2004; Yan et al., 2020), 5) Phytovolatilization is the conversion of toxic volatile elements into less toxic forms after being taken up from the soil and consequently released into the air through transpiration process via leaves (Mahar et al., 2016) This figure is created by BioRender software.

2005). Indoor plants are considered to be natural air filters as they can purify air through different methods: absorption, dilution, precipitation, and filtration (Kim et al., 2018; Lee, Hadibarata, and Yuniarto 2020). A well-known process carried out by plants is photosynthesis in which plants clean the air through taking in carbon dioxide and releasing oxygen. Respiration is another process where plants absorb oxygen and release carbon dioxide. Through photosynthesis and respiration, the air goes in and out from the stomata, as they are considered the main apparatus that plants use in the absorption and filtration mechanisms (Jones 1998). Plants can absorb airborne molecules and restore the ecological balance in the air (Agarwal et al., 2018). In addition, plants can purify the air from pollutants such as carbon dioxide, volatile organic components (VOC), carbonyl, particulate matter, organic compounds, nitrates, sulfates, ammonia, calcium, ozone, and carbonate. Indoor plants can be considered as a low-cost solution that reduces the levels of indoor pollutants and minimize human exposure to many harmful compounds (Pegas et al., 2012; Soreanu et al., 2013; Abbass et al., 2017; Parseh Iman et al., 2018; Wei et al., 2021).

Indoor relative humidity $(\mathrm{RH})$ is considered an important component which causes an interaction between humans, viruses, and plants. Recommended interior humidity levels for human comfort usually range between 30 and 60\% (Fan et al., 2017) and
40-60\% shows to prevent viral transmission (Audi et al., 2020). Research has shown that plants are capable of absorbing tiny airborne water vapor particles and have the ability to improve indoor humidity (Jeong et al., 2008; Pérez-Urrestarazu et al., 2016). Concerns were raised, that indoor plants transpire through stomata releasing tiny water droplets to the surrounding air, increasing humidity; however, at high humidity, the transpiration rate by plants decreases maintaining the interior humidity at suitable levels for humans. Pegas and colleagues stated that humidity is highly correlated with the abundance and presence of molds, bacteria, mildew, and other biological pathogens leading to a drastic impact on human health (Pegas et al., 2011). Plants are known for the potential to enhance the humidity through foliar water uptake at high humidity, thus reducing bioaerosols (Lohr and Pearson-Mims 1996; Limm et al., 2009; Gawrońska and Bakera 2014; Brilli et al., 2018; Chiam et al., 2019). Henceforth, plants can control air humidity maintaining it at intermediate levels which lower the viability of SAR-CoV-2 in liquid erosols that decrease the efficiency of viral transmission.

Plants can release in the air small quantities of secondary metabolites and their derivatives, such as polyphenols and alkaloids. This process is considered one of the plant's techniques to interact with the surrounding environment called Allelochemicals (Mushtaq et al., 2019). Those compounds were reported to have antimicrobial activities 
TABLE 2 | Household plants that have been tested to reduce airborne pathogens and pollutants.

\begin{tabular}{|c|c|c|c|c|c|}
\hline Scientific name & $\begin{array}{l}\text { Common } \\
\text { name }\end{array}$ & Family & Pathogen & Other indoor pollutants & References \\
\hline Ficus benjamina & Weeping fig & Moraceae & $\begin{array}{l}\text { Bacteria, } \\
\text { Actinomycetes and } \\
\text { Mold }\end{array}$ & $\begin{array}{l}\text { Formaldehyde } \\
\text { Volatile organic compounds }\end{array}$ & $\begin{array}{l}\text { Kim et al. (2008), Schmitz et al. (2000), Weidener } \\
\text { and Teixeira da Silva (2006), Wolverton and } \\
\text { Wolverton (1993), Wolverton and Wolverton (1996) }\end{array}$ \\
\hline Ficus alii & Alii ficus & Moraceae & $\begin{array}{l}\text { Bacteria, } \\
\text { Actinomycetes and } \\
\text { Mold }\end{array}$ & & $\begin{array}{l}\text { Wolverton and Wolverton (1993), Wolverton and } \\
\text { Wolverton (1996) }\end{array}$ \\
\hline Spathiphyllum sp. & Peace lily & Araceae & $\begin{array}{l}\text { Bacteria, } \\
\text { Actinomycetes and } \\
\text { Mold }\end{array}$ & Benzene & $\begin{array}{l}\text { Wolverton and Wolverton (1996), Parseh et al. } \\
\text { (2018b) }\end{array}$ \\
\hline $\begin{array}{l}\text { Chrysalidocarpus } \\
\text { lutescens }\end{array}$ & Areca palm & Arecaceae & $\begin{array}{l}\text { Bacteria, } \\
\text { Actinomycetes and } \\
\text { Mold }\end{array}$ & $\begin{array}{l}\text { Ammonia } \\
\text { Formaldehyde } \\
\text { Total volatile organic } \\
\text { compounds (TVOCs), } \mathrm{CO}_{2} \text {, } \\
\text { and } \mathrm{CO}\end{array}$ & $\begin{array}{l}\text { Wolverton and Wolverton (1996), EL Sayed (2020), } \\
\text { Bhargava et al. (2021) }\end{array}$ \\
\hline $\begin{array}{l}\text { Dracaena fragans } \\
\text { "Massangeana" }\end{array}$ & Corn plant & Asparagaceae & $\begin{array}{l}\text { Bacteria, } \\
\text { Actinomycetes and } \\
\text { Mold }\end{array}$ & $\begin{array}{l}\text { Benzene Ozone } \\
\text { Toluene Xylene Formaldehyde } \\
\text { Trichloro- ethylene }\end{array}$ & $\begin{array}{l}\text { Wolverton and Wolverton (1996), Chauhan et al. } \\
\text { (2017), Aydogan and Cerone (2021) }\end{array}$ \\
\hline Rhapis excelsa & Lady palm & Arecaceae & $\begin{array}{l}\text { Bacteria, } \\
\text { Actinomycetes and } \\
\text { Mold }\end{array}$ & Formaldehyde & $\begin{array}{l}\text { Wolverton and Wolverton (1996), Schmitz et al. } \\
\text { (2000), Aydogan and Cerone (2021) }\end{array}$ \\
\hline $\begin{array}{l}\text { Dracaena dermensis } \\
\text { "Warneckei" }\end{array}$ & Warneckei & Asparagaceae & $\begin{array}{l}\text { Bacteria, } \\
\text { Actinomycetes and } \\
\text { Mold }\end{array}$ & $\begin{array}{l}\text { Toluene } \\
\text { Xylene } \\
\text { Benzene } \\
\text { Ethylbenzene } \\
\text { Formaldehyde }\end{array}$ & $\begin{array}{l}\text { Godish and Guindon (1989), Wolverton and } \\
\text { Wolverton (1996), Mosaddegh et al. (2014) }\end{array}$ \\
\hline $\begin{array}{l}\text { Deiffenbachia "Exotica } \\
\text { compacta" }\end{array}$ & Dumb cane & Araceae & $\begin{array}{l}\text { Bacteria, } \\
\text { Actinomycetes and } \\
\text { Mold }\end{array}$ & $\begin{array}{l}\text { Toluene } \\
\text { Xylene }\end{array}$ & $\begin{array}{l}\text { Wolverton and Wolverton (1996), Sharma et al. } \\
\text { (2018) }\end{array}$ \\
\hline Deiffenbachia camille & Dumb cane & Araceae & $\begin{array}{l}\text { Bacteria, } \\
\text { Actinomycetes and } \\
\text { Mold }\end{array}$ & $\begin{array}{l}\text { Toluene } \\
\text { Xylene }\end{array}$ & $\begin{array}{l}\text { Wolverton and Wolverton (1996), Sharma et al. } \\
\text { (2018) }\end{array}$ \\
\hline $\begin{array}{l}\text { Philodendron } \\
\text { domesticum }\end{array}$ & Philodendron & Araceae & $\begin{array}{l}\text { Bacteria, } \\
\text { Actinomycetes and } \\
\text { Mold }\end{array}$ & Formaldehyde & $\begin{array}{l}\text { Wolverton and Wolverton (1996), Sharma et al. } \\
\text { (2018) }\end{array}$ \\
\hline Epipermum aureum & $\begin{array}{l}\text { Golden } \\
\text { pothos }\end{array}$ & Araceae & $\begin{array}{l}\text { Bacteria, } \\
\text { Actinomycetes and } \\
\text { Mold }\end{array}$ & Benzene & $\begin{array}{l}\text { Wolverton and Wolverton (1996), Gong et al. } \\
\text { (2019) }\end{array}$ \\
\hline $\begin{array}{l}\text { Syngonium } \\
\text { podophyllum }\end{array}$ & $\begin{array}{l}\text { Arrowhead } \\
\text { vine }\end{array}$ & Araceae & $\begin{array}{l}\text { Bacteria, } \\
\text { Actinomycetes and } \\
\text { Mold }\end{array}$ & $\begin{array}{l}\mathrm{CO}_{2} \\
\text { Volatile organic } \\
\text { compounds (VOC) } \\
\text { Benzene }\end{array}$ & $\begin{array}{l}\text { Wolverton and Wolverton (1996), Parseh et al. } \\
\text { (2018b) }\end{array}$ \\
\hline $\begin{array}{l}\text { Sanseveria frifasciata } \\
\text { "Laurenetii" }\end{array}$ & Snake plant & Asparagaceae & $\begin{array}{l}\text { Bacteria, } \\
\text { Actinomycetes and } \\
\text { Mold }\end{array}$ & & $\begin{array}{l}\text { Wolverton and Wolverton (1996), Seminar (2012), } \\
\text { Sharma et al. (2018) }\end{array}$ \\
\hline Codiaeum varigatium & $\begin{array}{l}\text { Croton } \\
\text { Ethylbenzene }\end{array}$ & Euphorbiaceae & $\begin{array}{l}\text { Bacteria, } \\
\text { Actinomycetes and } \\
\text { Mold }\end{array}$ & Toluene & $\begin{array}{l}\text { Wolverton and Wolverton (1996), Sriprapat et al. } \\
\text { (2014) }\end{array}$ \\
\hline Cyperus alternifolius & $\begin{array}{l}\text { Umbrella } \\
\text { grass }\end{array}$ & Cyperaceae & $\begin{array}{l}\text { Bacteria, } \\
\text { Actinomycetes and } \\
\text { Mold }\end{array}$ & & $\begin{array}{l}\text { Wolverton et al. (1989), Wolverton and Wolverton } \\
\text { (1996) }\end{array}$ \\
\hline
\end{tabular}

and can interact with airborne microbes close to the plant (Yang H. et al., 2012; Othman et al., 2019).

Experiments were performed showing the reduction of airborne pathogens by plants, as Wolverton et al. reported that indoor house plants are competent to reduce airborne microbes by $50 \%$, compared to indoor spaces lacking plants. Their data showed that hydroponic planter system containing 15 different houseplant species were able to directly and 


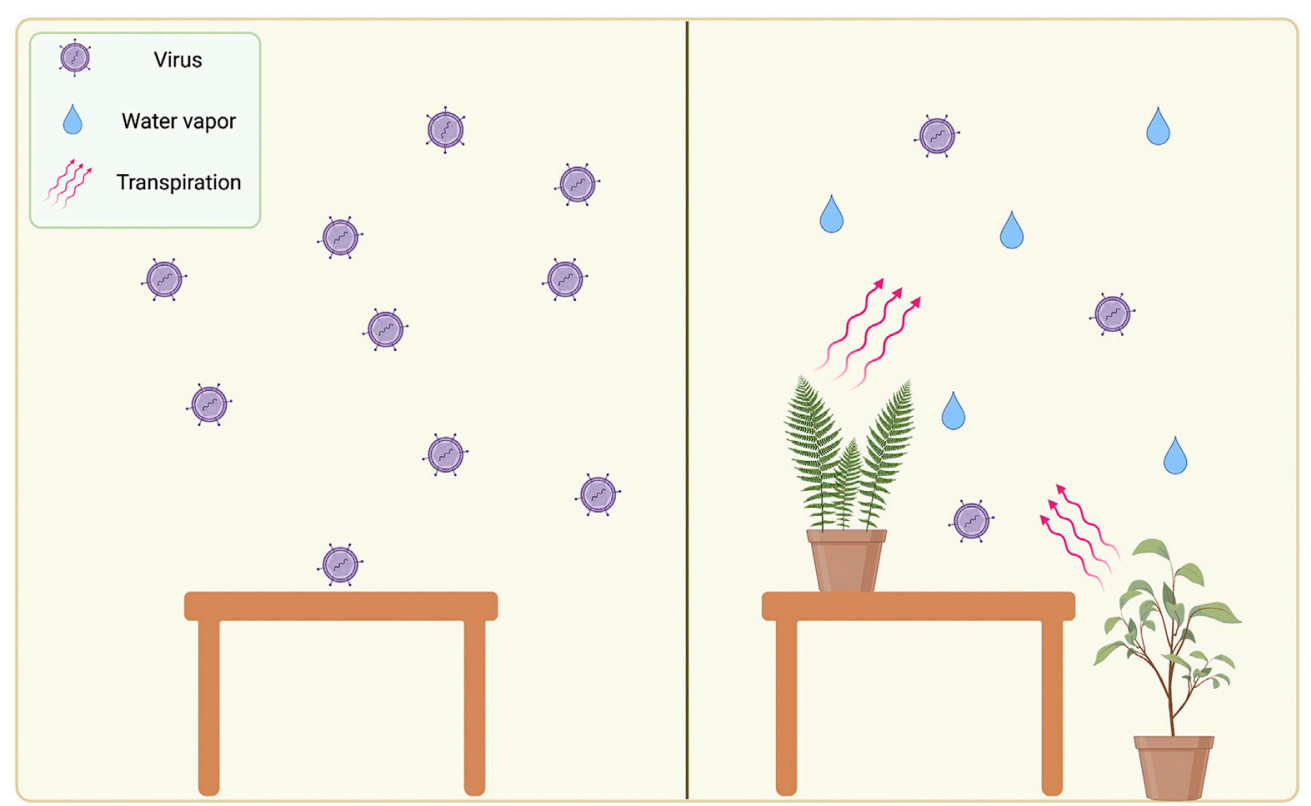

FIGURE 3 | illustration of the potential role of indoor plant in reducing airborne viruses via regulation of humidity. Left section represent a plant-free environment with low relative humidity and high viral transmission. Right section represents effect of plants on increasing the humidity and reducing the viral transmission. This figure is created by BioRender software.

indirectly suppress the growth of airborne microbes compared to the plant-free room, however they did not mention a specific species and no viruses were tested. The study discussed those volatile substances released by houseplants might be the main reason in controlling the airborne microbe population in plant-included environments (Wolverton and Wolverton 1996). A recent study showed that plants could significantly decrease air microbiomes when compared to plant-free sites, providing a healthier environment and reducing the exposure risk of airborne diseases (Li et al., 2021). Another study was conducted showing evidence that plants can reduce fine particles. In 2016, Stapleton evaluated 11 different household plant species, which showed a significant reduction of ultrafine particles in the indoor environment (Stapleton and Ruiz-Rudolph 2018). Table 2 summarizes different indoor plant species that were proven to reduce airborne pathogens and air pollutants.

There is lack of experimental evidence that indicated plants having a direct role in the reduction of virus transmission, through controlling the environment. Few approaches were conducted to provide evidence that plants are capable of affecting airborne microorganisms, including bacteria and fungi (Wolverton and Wolverton 1996; Pegas et al., 2011; Li et al., 2021); however, as yet none of these approaches tested the direct impact of indoor plants on virus survival and transmission. Further investigations are still required to elucidate the mechanisms by which different plants can reduce airborne microbes and to specify which plants would be best used to reduce bacteria and viruses from the air to limit indoor disease transmission.

\section{THE POTENTIAL ROLE OF INDOOR PLANT IN FIGHTING COVID-19 VIA REGULATION OF HUMIDITY}

The most probable role that plants can play in reducing SARSCoV-2 transmission is via modulating humidity in the indoor environment. Studies have shown that in humidity levels ranging from (40-60\%) influenza virus transmission decreased in genie pig, concluding that the virus became deactivated in these conditions (Yang Wan et al., 2012; Bhattacharyya et al., 2015). Also, the stability of the virus decreased in these conditions (Audi et al., 2020), via affecting the virus lipid envelope (Tang 2009). Attempted studies evaluated the effect of relative humidity on SARS-CoV-2 transmission, concluding that the virus transmission rates is reduced in high humidity conditions (Wang et al., 2020), also a study found that SARS-CoV is less viable at relative humidity $>50 \%$ (Chan et al., 2011). Other environmental factors might be involved in viral transmission such as temperature, light, airflow, and other unstated factors. As plants modulate indoor humidity in levels above 30\% (Kerschen et al., 2016), we propose that the use of indoor plants can regulate humidity in confined places, which will subsequently decrease the stability of the SARS-CoV-2 in air particles and reducing its transmission rate. The proposed role of indoor plants is described in Figure 3. 


\section{THE ROLE OF INDOOR PLANTS ON HUMAN HEALTH}

Plants play one of the prominent roles that increase the survival of humankind that is living healthy, which causes an enhanced immune system capable of fighting diseases. This role could be attained by eating balanced nutritious food and living in a healthy environment (EEA (European Environment Agency), 2020; Mathus-Vliegen 1995). Plants have been a key element in the human environment that directly and indirectly improve human health (Deng and Deng 2018). Directly, by providing humans with oxygen and food, plant extractions have been widely used in the pharmaceutical industry to aid in disease prevention and treatments (Ribnicky et al., 2002). While indirectly by improving the environment through air-purifying and removal of air pollutants (Qin et al., 2014). Additionally, indoor plants such as lemon balm and hyssop can be used as home remedies to aid in managing the symptoms of cold and flu (Doukani et al., 2021; Judžentiené 2016) Also, plants have a psychological effect that impacts human productivity and destressing that affects human immunity (Bringslimark et al., 2009). Indoor plants have been known to add an esthetic value to their surroundings. However, their effect on the human immune system and health, as well as psychological effects have not been fully investigated and quantified. A study has shown that indoor plants such as rubber tree, English ivy, and spider plants have increased the performance of students in classrooms (Kim et al., 2014). Another study has shown that the presence of indoor scented and unscented plants such as lavender, poinsettia, alocasia rhizome, and apple geranium enhanced human comfort (Qin et al., 2014). Moreover, plant photosynthesis has been shown to improve air quality by producing negative air ions. Additionally, plants remove pollutants, and volatile organic components (some examples are shown in Table 2); plants were also found to regulate temperature and humidity (Deng and Deng 2018). Overall, the presence of indoor plants has many benefits on human psychological health and enhancement of air quality. Nevertheless, the effect of indoor plants on human biological functions is not fully studied due to a lack of quantification methods.

\section{FUTURE PERSPECTIVE OF THE ROLE OF PLANTS IN FIGHTING SARS-COV-2 SPREAD}

The hypothesis illustrated above shows the need for further investigations and experiments to be conducted to prove the role of plants in reducing viral transmission not only specific to SARS$\mathrm{CoV} 2$ but as a general prospective to improve human health. As mentioned in previous sections, we suggest that indoor plants can serve as an economically and environmentally friendly solution to reduce SARS-CoV-2 spread in confined spaces, which can be used in low-income countries and households as a cheap alternative to complicated filtration systems. This suggestion could be achieved by enchaining the indoor environmental conditions to a much less friendly environment to the virus by increasing the humidity. However, this is a novel idea and studies are needed to confirm our suggested hypothesis. Studies investigating the effect of indoor plants on air quality are limited due to several reasons. For instance, the choice of the experimental site and the experimental setup, as several factors can affect the results; in addition, fine-tuned experimental designs to achieve accuracy incur high costs. These reasons have created a vast gap between theoretical bases and implementation. This lack of information is disappointing as the potentially discovered data might have an enormously beneficial effect on human health by protecting against harmful diseases and limiting viral transmission rates. Scholars and researchers need to establish a standardized protocol for a controlled indoor computerized experiment that mimics the indoor environment and implements artificial intelligence technology to monitor all factors. This protocol can minimize data errors and provide useful research guidelines that will eventually lead to a healthier human environment. In brief, implementing indoor plants to reduce SARS-CoV-2 transmission is an idea worth pursuing in the near future with a well-design experiment and controlled parameters to aid in our fight against the COVID-19 pandemic.

\section{CONCLUSION}

The COVID-19 pandemic spread has caused drastic changes in policies worldwide; reducing human contact has become preferable, and air bio-decontamination and surface sterilization have become necessary to control the high transmission rate of the virus. Additionally, studies have shown that the virus can stay for a long time and travel in the air in large and small droplets; consequently, high viral contamination rates were found in the air of poorly ventilated areas with recycled air such as hospitals. For all these reasons, air purification and bio-decontamination techniques are recommended to be used in all public and private indoor spaces to contain the spread of the virus in areas with poor ventilation. Especially as the virus could remain in the human population for a longer time than expected due to new strains being discovered worldwide which may escape the immune response. Air purification via filters, UV radiation and ionization could be used to clean the air in large companies and facilities. However, some drawbacks can limit using these techniques, such as high costs and the need for specialized maintenance, making these methods not applicable in rural areas, homes, developing counties, and low budget facilities. Therefore, a novel low-cost air purification method is highly preferable. The answer to this could be the use of the indoor plant to purify the air. Several studies have shown that indoor plants enhance air quality, remove pollutants, and reduce bacterial and fungal infection spread, none of which were on airborne viruses. The techniques by which plants purify the air are not fully understood, and limited research information is available discussing their role in controlling viral transmission. Furthermore, the propose role of plants regulating relative humidity in confined places could be considered an alternative solution that can be used to reduce the viability of SARS-CoV-2 and 
add esthetic value to the surrounding environment. In conclusion, more research in this area is required in the search for methods of lowering transmission rates in low-budget places, especially as the indoor plants were found to increase human comfort and enhance overall human health.

\section{AUTHOR CONTRIBUTIONS}

RE-T and SE-M conceived the idea. All authors reviewed the literature, drafted the manuscript, critically revised, and

\section{REFERENCES}

Abbass, O. A., Sailor, D. J., and Gall, E. T. (2017). Effectiveness of Indoor Plants for Passive Removal of Indoor Ozone. Building Environ. 119, 62-70. doi:10.1016/ j.buildenv.2017.04.007

Abdelrahman, Z., Li, M., and Wang, X. (2020). Comparative Review of SARS-CoV2, SARS-CoV, MERS-CoV, and Influenza A Respiratory Viruses. Front. Immunol. 11 (September). doi:10.3389/fimmu.2020.552909

Agarwal, P., Sarkar, M., Chakraborty, B., and Banerjee, T. (2018). Phytoremediation of Air Pollutants: Prospects and Challenges. Amsterdam, Netherlands: Elsevier.

Andersen, K. G., Rambaut, A., Lipkin, W. I., Holmes, E. C., and Garry, R. F. (2020). The Proximal Origin of SARS-CoV-2. Nat. Med. 26 (4), 450-452. doi:10.1038/ s41591-020-0820-9

Astuti, I., and Ysrafil, F. (2020). Severe Acute Respiratory Syndrome Coronavirus 2 (SARS-CoV-2): An Overview of Viral Structure and Host Response. Diabetes Metab. Syndr. Clin. Res. Rev. 14 (4), 407-412. doi:10.1016/j.dsx.2020.04.020

Audi, A., AlIbrahim, M., Kaddoura, M., Hijazi, G., Yassine, H. M., and Hassan, Z. (2020). Seasonality of Respiratory Viral Infections: Will COVID-19 Follow Suit?. Front. Public Health 8, 567184. doi:10.3389/fpubh.2020.567184

Aydogan, A., and Cerone, R. (2021). Review of the Effects of Plants on Indoor Environments. Indoor Built Environ. 30 (4), 442-460. doi:10.1177/ 1420326x19900213

Bazant, M. Z., and John, W. M. B. (2021). A Guideline to Limit Indoor Airborne Transmission of COVID-19. Proc. Natl. Acad. Sci. United States America 118 (17). doi:10.1073/pnas.2018995118

Belser, J. A., Rota, P. A., and Tumpey, T. M. (2013). Ocular Tropism of Respiratory Viruses. Microbiol. Mol. Biol. Rev. 77 (1), 144-156. doi:10.1128/mmbr.00058-12

Bhargava, B., Malhotra, S., Chandel, A., Rakwal, A., Kashwap, R. R., and Kumar, S. (2021). Mitigation of Indoor Air Pollutants Using Areca Palm Potted Plants in Real-Life Settings. Environ. Sci. Pollut. Res. 28 (7), 8898-8906. doi:10.1007/ s11356-020-11177-1

Bhattacharyya, S., Gesteland, P. H., Korgenski, K., Bjørnstad, O. N., and Adler, F. R. (2015). Cross-Immunity between Strains Explains the Dynamical Pattern of Paramyxoviruses. Proc. Natl. Acad. Sci. USA 112 (43), 13396-13400. doi:10.1073/pnas.1516698112

Billah, M. A., Miah, M. M., and Khan, M. N. (2020). Reproductive Number of Coronavirus: A Systematic Review and Meta-Analysis Based on Global Level Evidence. PLoS ONE 15 11, 1-17. doi:10.1371/journal.pone.0242128

Bluyssen, P. M., Ortiz, M., and Zhang., D. (2021). The Effect of a mobile HEPA Filter System on 'infectious' Aerosols, Sound and Air Velocity in the SenseLab. Building Environ. 188 (December 2020), 107475. doi:10.1016/ j.buildenv.2020.107475

Brilli, F., Fares, S., Ghirardo, A., de Visser, P., Calatayud, V., Muñoz, A., et al. (2018). Plants for Sustainable Improvement of Indoor Air Quality. Trends Plant Sci. 23 (6), 507-512. doi:10.1016/j.tplants.2018.03.004

Bringslimark, T., Hartig, T., and Patil, G. G. (2009). The Psychological Benefits of Indoor Plants: A Critical Review of the Experimental Literature. J. Environ. Psychol. 29 (4), 422-433. doi:10.1016/j.jenvp.2009.05.001

Brooks, S. K., Webster, R. K., and Smith, L. E. (2020). Lisa Woodland, Simon Wessely, Neil Greenberg, and Gideon James Rubin. 2020. "The Psychological Impact of Quarantine and How to Reduce it: Rapid Review of the Evidence. The Lancet 395 (10227), 912-920. doi:10.1016/s0140-6736(20)30460-8 approved the final version before submission. All authors have read and agreed to the published version of the manuscript.

\section{ACKNOWLEDGMENTS}

The authors would also like to thank Prof. Mamduh El-Messeiry for his valuable input on the air filtration section. The authors show their appreciation to Yasmin ElMaglhoob for her English editing and valuable input.

Brown, J. H., Cook, K. M., Ney, F. G., and Hatch, T. (1950). Influence of Particle Size upon the Retention of Particulate Matter in the Human Lung. Am. J. Public Health Nations Health 40 (4), 450-480. doi:10.2105/ajph.40.4.450

Callaway, E. (2020). The Coronavirus Is Mutating - Does it Matter?. Nature 585 (7824), 174-177. doi:10.1038/d41586-020-02544-6

Chan, J. F.-W., Yuan, S., Kok, K.-H., To, K. K.-W. T., Chu, H., Yang, J., et al. (2020). A Familial Cluster of Pneumonia Associated with the 2019 Novel Coronavirus Indicating Person-To-Person Transmission: A Study of a Family Cluster. The Lancet 395 (10223), 514-523. doi:10.1016/s01406736(20)30154-9

Chan, K. H., Peiris, J. S. Mali., Lam, S. Y., Poon, L. L. M., Yuen, K. Y., and Seto, W. H. (2011). The Effects of Temperature and Relative Humidity on the Viability of the SARS Coronavirus. Adv. Virol. 2011, 734690. doi:10.1155/2011/734690

Chauhan, P., Singh Rawat, M., and Gauba, P. (2017). Role of Plants in Indoor Air Remediation. Int. J. Eng. Tech. Sci. Res. 4 (9), 749-756.

Cherry, J. D., and Krogstad, P. (2004). SARS: The First Pandemic of the 21st Century. Pediatr. Res. 56 (1), 1-5. doi:10.1203/01.pdr.0000129184.87042.fc

Chiam, Z., Song, X. P., Lai, H. R., and Tan, H. T. W. (2019). Particulate Matter Mitigation via Plants: Understanding Complex Relationships with Leaf Traits. Sci. Total Environ. 688, 398-408. doi:10.1016/j.scitotenv.2019.06.263

Christopherson, D. A., Yao, W. C., Lu, M., Vijayakumar, R., and Sedaghat, A. R. (2020). High-Efficiency Particulate Air Filters in the Era of COVID-19: Function and Efficacy. Otolaryngol. Head Neck Surg. 163 (6), 1153-1155. doi: $10.1177 / 0194599820941838$

Chuaybamroong, P., Chotigawin, R., Supothina, S., Sribenjalux, P., Larpkiattaworn, S., and Wu, C.-Y. (2010). Efficacy of Photocatalytic HEPA Filter on Microorganism Removal. Indoor Air 20 (3), 246-254. doi:10.1111/j.16000668.2010.00651.x

Cuevas, J. M., Geller, R., Garijo, R., López-Aldeguer, J., and Sanjuán, R. (2015). Extremely High Mutation Rate of HIV-1 In Vivo. PLoS Biol. 13 (9), 1-19. doi:10.1371/journal.pbio.1002251

Cunningham, S. D., Berti, W. R., and Huang, J. W. (1995). Phytoremediation of Contaminated Soils. Trends Biotechnol. 13 (9), 393-397. doi:10.1016/s01677799(00)88987-8

Davidson, A. M., Jan, W., and Daniel, B. (2020). Interaction of SARS-CoV-2 and Other Coronavirus with ACE (Angiotensin-Converting Enzyme)-2 as Their Main Receptor: Therapeutic Implications. Hypertension 76, 1339-1349. doi:10.1161/HYPERTENSIONAHA.120.15256

Dee, S. A., Deen, J., Cano, J. P., Batista, L., and Pijoan, C. (2006). Further Evaluation of Alternative Air-Filtration Systems for Reducing the Transmission of Porcine Reproductive and Respiratory Syndrome Virus by Aerosol. Can. J. Vet. Res. 70 (3), 168-175

Deng, L., and Deng, Q. (2018). The Basic Roles of Indoor Plants in Human Health and Comfort. Environ. Sci. Pollut. Res. 25 (36), 36087-36101. doi:10.1007/ s11356-018-3554-1

Desai, S., Rashmi, S., Rane, A., Dharavath, B., Sawant, A., and Dutt, A. (2021). An Integrated Approach to Determine the Abundance, Mutation Rate and Phylogeny of the SARS-CoV-2 Genome. Brief. Bioinform. 22 (2), 1065-1075. doi:10.1093/bib/bbaa437

Dhama, K. (2020). Update on COVID-19, 10-2020. Clin. Microbiol. Rev. 33 (4), 1-48. doi:10.1128/CMR.00028-20

Doukani, K., Selles, A. S. M., and Bouhenni, H. (2021). "Chapter 3.2.3 - Melissa Officinalis (Lemon Balm)," in Naturally Occurring Chemicals against 
Alzheimer's Disease. Editors T. Belwal, S. M. Nabavi, S. F. Nabavi, A. R. Dehpour, and S. Shirooie (Cambridge, MA: Academic Press), 225-241.

EEA (European Environment Agency) (2020). "Healthy Environment, Healthy Lives: How the Environment Influences Health and Wellbeing in Europe,". EEA Report No. 21/2019.

El Sayed, N. (2020). Purification of Indoor Air from Pollutants by Areca Palm (Chrysalidocarpus Lutescens L.) Treated with Some Non-enzymatic Antioxidants. J. Plant Prod. 11 (5), 545-553. doi:10.21608/jpp.2020.102767

Ethington, T., Newsome, S., Waugh, J., and Lee, L. D. (2018). Cleaning the Air with Ultraviolet Germicidal Irradiation Lessened Contact Infections in a Long-Term Acute Care Hospital. Am. J. Infect. Control. 46 (5), 482-486. doi:10.1016/ j.ajic.2017.11.008

Fan, G., Xie, J., Yang, H., and Liu, J. (2017). Improving Indoor Air Humidity in Heated Rooms Based on Natural Evaporation of Water from Wetted Textile Fabric - A Pilot Study. Proced. Eng. 205, 1302-1309. doi:10.1016/ j.proeng.2017.10.384

Fehr, A. R., Channappanavar, R., and Perlman, S. (2017). Middle East Respiratory Syndrome: Emergence of a Pathogenic Human Coronavirus. Annu. Rev. Med. 68, 387-399. doi:10.1146/annurev-med-051215-031152

Fennelly, K. P. (2020). Particle Sizes of Infectious Aerosols: Implications for Infection Control. Lancet Respir. Med. 8 (9), 914-924. doi:10.1016/s22132600(20)30323-4

Garfin, D. R. (2020). Technology as a Coping Tool during the Coronavirus Disease 2019 (COVID-19) Pandemic: Implications and Recommendations. Stress and Health 36 (4), 555-559. doi:10.1002/smi.2975

Gawrońska, H., and Bakera, B. (2014). Phytoremediation of Particulate Matter from Indoor Air by Chlorophytum Comosum L. Plants. Air Qual. Atmosphere Health 8, 265-272. doi:10.1007/s11869-014-0285-4

Godish, T., and Guindon, C. (1989). An Assessment of Botanical Air Purification as a Formaldehyde Mitigation Measure under Dynamic Laboratory Chamber Conditions. Environ. Pollut. 62 (1), 13-20. doi:10.1016/0269-7491(89)90092-4

Gong, Y., Zhou, T., Wang, P., Lin, Y., Zheng, R., Zhao, Y., et al. (2019). Fundamentals of Ornamental Plants in Removing Benzene in Indoor Air. Atmosphere 10 (4). doi:10.3390/atmos10040221

Gordon, D. E., Jang, G. M., Bouhaddou, M., Xu, J., Obernier, K., White, K. M., et al. (2020). A SARS-CoV-2 Protein Interaction Map Reveals Targets for Drug Repurposing. Nature 583 (7816), 459-468. doi:10.1038/s41586-020-2286-9

Grabarczyk, Z. (2001). Effectiveness of Indoor Air Cleaning with Corona Ionizers. J. Electrostatics 51-52 (52), 278-283. doi:10.1016/s0304-3886(01)00058-4

Hagbom, M., Nordgren, J., Rolf, N., Hedlund, K. O., Wigzell, H., and Svensson, L. (2015). Ionizing Air Affects Influenza Virus Infectivity and Prevents AirborneTransmission. Scientific Rep. 5, 1-10. doi:10.1038/srep11431

Hamming, I., Timens, W., Bulthuis, M., Lely, A., Navis, G., and van Goor, H. (2004). Tissue Distribution of ACE2 Protein, the Functional Receptor for SARS Coronavirus. A First Step in Understanding SARS Pathogenesis. J. Pathol. 203 (2), 631-637. doi:10.1002/path.1570

Harapan, H., Itoh, N., Yufika, A., Winardi, W., Keam, S., Te, H., et al. (2020). Coronavirus Disease 2019 (COVID-19): A Literature Review. J. Infect. Public Health 13 (5), 667-673. doi:10.1016/j.jiph.2020.03.019

Harper, G. J., and Morton, J. D. (1953). The Respiratory Retention of Bacterial Aerosols: Experiments with Radioactive Spores. J. Hyg. 51 (3), 372-385. doi:10.1017/s0022172400015801

Health, W. H. O.Emergencies Programme; Experts Advisory Panel; I. P. C. Preparedness; I. P. C. Guidance; Development Group; I. P. C. Gdg; Strategic Preparedness; Response Plan (2020). Transmission of SARS-CoV-2: Implications for Infection Prevention Precautions. (July):1-10. Geneva, Switzerland: WHO.

History, B. (2019). Psychiatry of Pandemics. Psychiatry of Pandemics. doi:10.3325/ cmj.2020.61.306

Holmes, K. V. (1999). "CORONAVIRUSES (CORONAVIRIDAE)," in Encyclopedia of Virology (Second Edition). Editors A. Granoff and R. G. Webster (Oxford, United Kingdom: Elsevier), 291-298.

Hosseini, E. S., Kashani, N. R., Nikzad, H., Azadbakht, J., Bafrani, H. H., and Haddad Kashani, H. (2020). The Novel Coronavirus Disease-2019 (COVID19): Mechanism of Action, Detection and Recent Therapeutic Strategies. Virology 551, 1-9. doi:10.1016/j.virol.2020.08.011

Hu, B., Guo, H., Zhou, P., and Shi, Z. Li. (2020). Characteristics of SARS-CoV-2 and COVID-19. Nat. Rev. Microbiol. 19, 141. doi:10.1038/s41579-020-00459-7
Huang, Y., Yang, C., Xu, X.-f., Xu, W., and Liu, S.-w. (2020). Structural and Functional Properties of SARS-CoV-2 Spike Protein: Potential Antivirus Drug Development for COVID-19. Acta Pharmacol. Sin 41 (9), 1141-1149. doi:10.1038/s41401-020-0485-4

Ii; Part; The Positive; Sense Single; Stranded Rna (2005). “The Positive Sense Single Stranded RNA Viruses," in Virus Taxonomy: Eighth Report of the International Committee on Taxonomy of Viruses (Figure 1), 739-1128.

Islam, K. U., and Iqbal, J. (2020). An Update on Molecular Diagnostics for COVID19. Front. Cell Infect. Microbiol. 10 (November), 1-11. doi:10.3389/ fcimb. 2020.560616

ISO 29463-1:2011 (2017). High Efficiency Filters and Filter Media for Removing Particles from Air - Part 1: Classification, Performance, Testing and Marketing. 61010-1 (C) Iec:2001 2014, 13.

Jeong, S. J., Song, J. S., Kim, W. S., Lee, D. W., Kim, H. D., Kim, K. J., et al. (2008). Evaluation of Selected Foliage Plants for Improvement of Indoor Humidity. Hort. Environ. Biotechnol. 49 (6), 439-446.

Jia, Y., Shen, G., Zhang, Y., Huang, K. S., Ho, H. Y., Hor, W. S., et al. (2020). Analysis of the Mutation Dynamics of SARS-CoV-2 Reveals the Spread History and Emergence of RBD Mutant with Lower ACE2 Binding Affinity. BioRxiv. doi:10.1101/2020.04.09.034942

Jiang, F., Deng, L., Zhang, L., Cai, Y., Cheung, C. W., and Xia, Z. (2020). Review of the Clinical Characteristics of Coronavirus Disease 2019 (COVID-19). J. Gen. Intern. Med. 35 (5), 1545-1549. doi:10.1007/s11606-020-05762-w

Johnson, W. E. (2019). Origins and Evolutionary Consequences of Ancient Endogenous Retroviruses. Nat. Rev. Microbiol. 17 (6), 355-370. doi:10.1038/ s41579-019-0189-2

Jones, H. (1998). Stomatal Control of Photosynthesis and Transpiration. J. Exp. Bot. 49, 387-398. doi:10.1093/jexbot/49.suppl_1.387

Judžentienè, A. (2016). "Chapter 53 - Hyssop (Hyssopus Officinalis L.) Oils," in Essential Oils in Food Preservation, Flavor and Safety. Editor V. R. Preedy (San Diego: Academic Press), 471-479.

Karia, R., Gupta, I., Khandait, H., Yadav, A., and Yadav, A. (2020). COVID-19 and its Modes of Transmission. SN Compr. Clin. Med. 2 (10), 1798-1801. doi:10.1007/s42399-020-00498-4

Kasmi, Y., Khataby, K., Amal, S., and Ennaji, M. M. (2019). "Coronaviridae: 100,000 Years of Emergence and Reemergence," in Emerging and Reemerging Viral Pathogens: Volume 1: Fundamental and Basic Virology Aspects of Human (Amsterdam, Netherlands: Elsevier), 127-149.

Kerschen, E. W., Garten, C., Williams, K. A., and Derby, M. M. (2016). Evapotranspiration from Spider and Jade Plants Can Improve Relative Humidity in an Interior Environment. HortTechnology 26 (6), 803-810. doi:10.21273/horttech03473-16

Kim, D., Lee, J.-Y., Yang, J.-S., Yang, J. W., Kim, V. N., Chang, V. H., et al. (2020). The Architecture of SARS-CoV-2 Transcriptome. Cell 181 (4), 914-921.e10. doi:10.1016/j.cell.2020.04.011

Kim, H-H., Yang, J-Y., Lee, J-Y., Park, J-W., Kim, K-J., Lim, B-S., et al. (2014). House-Plant Placement for Indoor Air Purification and Health Benefits on Asthmatics. Environ. Health Toxicol. 29, e2014014. doi:10.5620/ eht.e2014014

Kim, K. J., Kil, M. J., Song, J. S., Yoo, E. H., Son, K. C., Kays, S. J., et al. (2008). Efficiency of Volatile Formaldehyde Removal by Indoor Plants: Contribution of Aerial Plant Parts versus the Root Zone. J. Am. Soc. Hortic. Sci. 133 (4), 521-526. doi:10.21273/JASHS.133.4.521

Kim, K. J., Khalekuzzaman, M., Suh, J. N., Kim, H. J., Shagol, C., Kim, H.-H., et al. (2018). Phytoremediation of Volatile Organic Compounds by Indoor Plants: A Review. Hortic. Environ. Biotechnol. 59 (2), 143-157. doi:10.1007/s13580-0180032-0

Korber, B., Fischer, W. M., Gnanakaran, S., Yoon, H., Theiler, J., Abfalterer, W., et al. (2020). Tracking Changes in SARS-CoV-2 Spike: Evidence that D614G Increases Infectivity of the COVID-19 Virus. Cell 182 (4), 812-827.e19. doi:10.1016/j.cell.2020.06.043

Kujundzic, E., Matalkah, F., Howard, C. J., Hernandez, M., and Miller, S. L. (2006). UV Air Cleaners and Upper-Room Air Ultraviolet Germicidal Irradiation for Controlling Airborne Bacteria and Fungal Spores. J. Occup. Environ. Hyg. 3 (10), 536-546. doi:10.1080/15459620600909799

Kumar, M., and Khodor, S. A. (2020). Pathophysiology and Treatment Strategies for COVID-19. J. Translational Med. 18 (1), 1-9. doi:10.1186/s12967-020 02520-8 
Lee, B. X. Y., Hadibarata, T., and Yuniarto, A. (2020). Phytoremediation Mechanisms in Air Pollution Control: A Review. Water Air Soil Pollut. 231 (8), 437. doi:10.1007/s11270-020-04813-6

Lee, J. H. (2013). An Overview of Phytoremediation as a Potentially Promising Technology for Environmental Pollution Control. Biotechnol. Bioproc. E 18 (3), 431-439. doi:10.1007/s12257-013-0193-8

Li, H., Wu, Z. F., Yang, X. R., An, X. L., Ren, Y., and Su, J. Q. (2021). Urban Greenness and Plant Species Are Key Factors in Shaping Air Microbiomes and Reducing Airborne Pathogens. Environ. Int. 153 (August), 106539. doi:10.1016/ j.envint.2021.106539

Li, X., Luk, H. K. H., Lau, S. K. P., and Woo, P. C. Y. (2019). Human Coronaviruses: General Features. Amsterdam, Netherlands: Elsevier. doi:10.1016/b978-0-12801238-3.95704-0

Limm, E. B., Simonin, K. A., Bothman, A. G., and Dawson, T. E. (2009). Foliar Water Uptake: A Common Water Acquisition Strategy for Plants of the Redwood Forest. Oecologia 161 (3), 449-459. doi:10.1007/s00442-0091400-3

Liu, J., Liao, X., Shen, Q., Yuan, J., Wang, F., Liu, Y., et al. (2020a). Community Transmission of Severe Acute Respiratory Syndrome Coronavirus 2, Shenzhen, China, 2020. Emerging Infect. Dis. 26 (6), 1320-1323. doi:10.3201/eid2606.200239

Liu, J., Xie, W., Wang, Y., Xiong, Y., Chen, S., Han, J., et al. (2020b). A Comparative Overview of COVID-19, MERS and SARS: Review Article. Int. J. Surg. 81, 1-8. doi:10.1016/j.ijsu.2020.07.032

Liu, Q., Xu, K., Wang, X., and Wang, W. (2020). From SARS to COVID-19: What Lessons Have We Learned?. J. Infect. Public Health 13 (11), 1611-1618. doi:10.1016/j.jiph.2020.08.001

Liu, Y., Gayle, A. A., Wilder-Smith, A., and Rocklöv, J. (2020). The Reproductive Number of COVID-19 Is Higher Compared to SARS Coronavirus. J. Trav. Med. 27 (2), 1-4. doi:10.1093/jtm/taaa021

Lohr, V. I., and Pearson-Mims, C. H. (1996). Particulate Matter Accumulation on Horizontal Surfaces in Interiors: Influence of Foliage Plants. Atmos. Environ. 30 (14), 2565-2568. doi:10.1016/1352-2310(95)00465-3

Lu, R., Zhao, X., Li, J., Niu, P., Yang, B., Wu, H., et al. (2020). Genomic Characterisation and Epidemiology of 2019 Novel Coronavirus: Implications for Virus Origins and Receptor Binding. The Lancet 395 (10224), 565-574. doi:10.1016/s0140-6736(20)30251-8

Luengas, A., Barona, A., Hort, C., Gallastegui, G., Platel, V., and Elias, A. (2015). A Review of Indoor Air Treatment Technologies. Rev. Environ. Sci. Biotechnol. 14 (3), 499-522. doi:10.1007/s11157-015-9363-9

MacLachlan, N. J., Dubovi, E. J., Barthold, S. W., Swayne, D. E., and Winton, J. R. (2017). Chapter 14 - Retroviridae. Fenner's Vet. Virol., 269-297.

Mahar, A., Wang, P., Ali, A., Awasthi, M. K., Lahori, A. H., Lahori, A. H., et al. (2016). Challenges and Opportunities in the Phytoremediation of Heavy Metals Contaminated Soils: A Review. Ecotoxicology Environ. Saf. 126, 111-121. doi:10.1016/j.ecoenv.2015.12.023

Martín-Alonso, S., Frutos-Beltrán, E., and Menéndez-Arias, L. (2021). Reverse Transcriptase: From Transcriptomics to Genome Editing. Trends Biotechnol. 39 (2), 194-210. doi:10.1016/j.tibtech.2020.06.008

Mathus-Vliegen, E. M. (1995). [Healthy Diet]. Ned Tijdschr Tandheelkd 102 (5), 189-193.

McAleer, M. (2020). Prevention Is Better Than the Cure: Risk Management of COVID-19. J. Risk Financial Manag. 13 (3), 46. doi:10.3390/jrfm13030046

Megahed, N. A., and Ghoneim, E. M. (2021). Indoor Air Quality: Rethinking Rules of Building Design Strategies in Post-Pandemic Architecture. Environ. Res. 193 (August 2020), 110471. doi:10.1016/j.envres.2020.110471

Menut, L., Bessagnet, B., Siour, G., Mailler, S., Pennel, R., and Cholakian, A. (2020). Impact of Lockdown Measures to Combat Covid-19 on Air Quality over Western Europe. Sci. Total Environ. 741, 140426. doi:10.1016/ j.scitotenv.2020.140426

Mesjasz-Przybyłowicz, J., Nakonieczny, M., Migula, P., Augustyniak, M., Tarnawska, M., Reimold, W., et al. (2004). Uptake of Cadmium, lead, Nickel and Zinc from Soil and Water Solutions by the Nickel Hyperaccumulator Berkheya Coddii. Acta Biologica Cracoviensia. Ser. botanica 46 (2), 75-85.

Morawska, L., Tang, J. W., Bahnfleth, W., Bluyssen, P. M., Boerstra, A., Buonanno, G., et al. (2020). How Can Airborne Transmission of COVID-19 Indoors Be Minimised?. Environ. Int. 142, 105832. doi:10.1016/j.envint.2020.105832
Morikawa, H., and Erkin, Ö. C. (2003). Basic Processes in Phytoremediation and Some Applications to Air Pollution Control. Chemosphere 52 (9), 1553-1558. doi:10.1016/s0045-6535(03)00495-8

Mosaddegh, M. H., Jafarian, A., Ghasemi, A., and Mosaddegh, A. (2014). Phytoremediation of Benzene, Toluene, Ethylbenzene and Xylene Contaminated Air by D. Deremensis and O. Microdasys Plants. J. Environ. Health Sci. Eng. 12 (1), 1-7. doi:10.1186/2052-336x-12-39

Muhammad, S., Long, X., and Salman, M. (2020). COVID-19 Pandemic and Environmental Pollution: A Blessing in Disguise?. Sci. Total Environ. 728, 138820. doi:10.1016/j.scitotenv.2020.138820

Mukhtar, K., Javed, K., Arooj, M., and Sethi, A. (2020). Advantages, Limitations and Recommendations for Online Learning during Covid19 Pandemic Era. Pak J. Med. Sci. 36 (COVID19-S4), S27-S31. doi:10.12669/pjms.36.covid19-s4.2785

Mushtaq, W., Siddiqui, M. B., and Rehman Hakeem, K. (2019). Allelopathy Potential for Green Agriculture. Vol. I. New York, NY: Springer.

Nazarenko, Y. (2021). Air Filtration and SARS-CoV-2. Epidemiol. Health 42, 19-21. doi:10.4178/epih.e2020049

Newman, L. A., Strand, S. E., Choe, N., Duffy, J., Ekuan, G., Ruszaj, M., et al. (1997). Uptake and Biotransformation of Trichloroethylene by Hybrid Poplars. Environ. Sci. Technol. 31 (4), 1062-1067. doi:10.1021/es960564w

Noti, J. D., Blachere, F. M., McMillen, C. M., Lindsley, W. G., Kashon, M. L., Slaughter, D. R., et al. (2013). High Humidity Leads to Loss of Infectious Influenza Virus from Simulated Coughs. PLoS ONE 8 (2), 2-9. doi:10.1371/ journal.pone.0057485

Othman, L., Sleiman, A., and Abdel-massih, R. M. (2019). Antimicrobial Activity of Polyphenols and Alkaloids in Middle Eastern Plants. Front. Microbiol. 10 (May), 911. doi:10.3389/fmicb.2019.00911

Pagliano, P., and Kafil, H. S. (2020). Protection and Disinfection Policies. Le Inferziono in Medicina 2 (April), 185-191.

Parseh, I., Teiri, H., Hajizadeh, Y., and Ebrahimpour, K. (2018a). Phytoremediation of Benzene Vapors from Indoor Air by Sche Ffl Era Arboricola and Spathiphyllum Wallisii Plants. Atmos. Pollut. Res. (April), 0-1. doi:10.1016/ j.apr.2018.04.005

Parseh, I., Teiri, H., Hajizadeh, Y., and Ebrahimpour, K. (2018b). Phytoremediation of Benzene Vapors from Indoor Air by Schefflera Arboricola and Spathiphyllum Wallisii Plants. Atmos. Pollut. Res. 9 (6), 1083-1087. doi:10.1016/j.apr.2018.04.005

Payne, S. (2017). Family Coronaviridae. Viruses, 149-158. doi:10.1016/B978-0-12803109-4.00017-9

Pegas, P. N., Alves, C. A., Evtyugina, M. G., Nunes, T., Cerqueira, M., Franchi, M., et al. (2011). Seasonal Evaluation of Outdoor/Indoor Air Quality in Primary Schools in Lisbon. J. Environ. Monit. 13 (3), 657-667. doi:10.1039/ c0em00472c

Pegas, P. N., Alves, C. A., Nunes, T., Bate-Epey, E. F., Evtyugina, M., and Pio, C. A. (2012). Could Houseplants Improve Indoor Air Quality in Schools?. J. Toxicol. Environ. Health A 75 (22-23), 1371-1380. doi:10.1080/ 15287394.2012.721169

Pérez-Urrestarazu, L., Fernández-Cañero, R., Franco, A., and Egea, G. (2016). Influence of an Active Living Wall on Indoor Temperature and Humidity Conditions. Ecol. Eng. 90, 120-124. doi:10.1016/ j.ecoleng.2016.01.050

Petrosillo, N., Viceconte, G., Ergonul, O., Ippolito, G., and Petersen, E. (2020). “COVID-19, SARS and MERS: Are They Closely Related?," in Clinical Microbiology and Infection (January).

Pilon-Smits, E. (2005). Phytoremediation. Annu. Rev. Plant Biol. 56, 15-39. doi:10.1146/annurev.arplant.56.032604.144214

Pushpawela, B., Jayaratne, R., Nguy, A., and Morawska, L. (2017). Efficiency of Ionizers in Removing Airborne Particles in Indoor Environments. J. Electrostatics 90 (September), 79-84. doi:10.1016/j.elstat.2017.10.002

Qin, J., Sun, C., Zhou, X., Leng, H., and Lian, Z. (2014). The Effect of Indoor Plants on Human Comfort. Indoor Built Environ. 23 (5), 709-723. doi:10.1177/ $1420326 \times 13481372$

Raeiszadeh, M., and Adeli, B. (2020). A Critical Review on Ultraviolet Disinfection Systems against COVID-19 Outbreak: Applicability, Validation, and Safety Considerations. ACS Photon. 7 (11), 2941-2951. doi:10.1021/ acsphotonics.0c01245 
Rahman, H. S., Aziz, M. S., Hussein, R. H., Omer, S. H. S., Khalid, E. S., Abdulrahman, N. A., et al. (2020). The Transmission Modes and Sources of COVID-19: A Systematic Review. Int. J. Surg. Open 26, 125-136. doi:10.1016/j.ijso.2020.08.017

Raskin, I., Ribnicky, D. M., Komarnytsky, S., Ilic, N., Poulev, A., Borisjuk, N., et al. (2002). Plants and Human Health in the Twenty-First Century. Trends Biotechnol. 20 (12), 522-531. doi:10.1016/s0167-7799(02)02080-2

Read, J. M., Bridgen, J. R. E., Cummings, D. A. T., Antonia, H., and Jewell, C. P. (2020). Novel Coronavirus 2019-NCoV: Early Estimation of Epidemiological Parameters and Epidemic Predictions. MedRxiv 2020 (January). doi:10.1098/ rstb.2020.0265

Roca-Ho, H., Riera, M., Palau, V., Pascual, J., and Soler, M. J. (2017). Characterization of ACE and ACE2 Expression within Different Organs of the NOD Mouse. Int. J. Mol. Sci. 18 (3), 563. doi:10.3390/ijms18030563

Roelants, P., Boon, B., and Lhoest, W. (1968). Evaluation of a Commercial Air Filter for Removal of Virus from the Air. Appl. Microbiol. 16 (10), 1465-1467. doi:10.1128/aem.16.10.1465-1467.1968

Sabino, C. P., Sellera, F. P., Sales-Medina, D. F., Machado, R. R. G., Durigon, E. L., Freitas-Junior, L. H., et al. (2020). UV-C (254 Nm) Lethal Doses for SARS-CoV2. Photodiagnosis Photodynamic Ther. 32, 101995. doi:10.1016/ j.pdpdt.2020.101995

Samavati, L., and Uhal, B. D. (2020). ACE2, Much More Than Just a Receptor for SARS-COV-2. Front. Cell Infect. Microbiol. 10 (June), 1-9. doi:10.3389/ fcimb. 2020.00317

Sandle, T. (2013). "Cleanrooms, Isolators and Cleanroom Technology," in Sterility, Sterilisation and Sterility Assurance for Pharmaceuticals, 189-207.

Sandle, T. (2020). Consideration of Covid-19 Prevention Measures for Those Working in GMP Pharmaceuticals and Healthcare Facilities. J. Validation Tech. 26 (2), 2.

Sandle, T. (2021). Review of the Efficacy of HEPA Filtered Air to Control Coronavirus Risks in Cleanrooms. Eur. J. Parenter. Pharm. Sci. 25 (2), 1-5. doi:10.37521/25203

Santarpia, J., Rivera, D., Herrera, V., Jane Morwitzer, M., Creager, H., Santarpia, G., et al. (2020). Transmission Potential of SARS-CoV-2 in Viral Shedding Observed at the University of Nebraska Medical Center. Scientific Rep., 1-12. doi:10.1101/2020.03.23.20039446

Schmitz, H., Hilgers, U., and Weidner, M. (2000). Assimilation and Metabolism of Formaldehyde by Leaves Appear Unlikely to Be of Value for Indoor Air Purification. New Phytol. 147 (2), 307-315. doi:10.1046/j.1469-8137.2000.00701.x

Seminar, E. (2012). Indoor Air, Quality Feb, and Environmental Architecture. Indoor Air Qual. 93 (Ci), 8554. doi:10.1051/matecconf/20179303001

Sharma, S. D., Jain, P. K., and Sharma, V. (2018). Cleanest, Greenest Solution for Maintaining Indoor Air Quality in Urban Areas: Plants. Ijtsrd 2 (2), 1442-1450. doi:10.31142/ijtsrd10760

Shereen, M. A., Khan, S., Kazmi, A., Bashir, N., and Siddique, R. (2020). COVID-19 Infection: Emergence, Transmission, and Characteristics of Human Coronaviruses. J. Adv. Res. 24, 91-98. doi:10.1016/j.jare.2020.03.005

Shiue, A., Hu, S.-C., and Tu, M.-L. (2011). Particles Removal by Negative Ionic Air Purifier in Cleanroom. Aerosol Air Qual. Res. 11 (2), 179-186. doi:10.4209/ aaqr.2010.06.0048

Siegel, J. D., Rhinehart, E., Jackson, M., and Chiarello, L. (2019). 2007 Guideline for Isolation Precautions: Preventing Transmission of Infectious Agents in Health Care Settings. Am. J. Infect. Control. 35, S65-S164. doi:10.1016/ j.ajic.2007.10.007

Soreanu, G., Dixon, M., and Darlington, A. (2013). Botanical Biofiltration of Indoor Gaseous Pollutants - A Mini-Review. Chem. Eng. J. 229, 585-594. doi:10.1016/j.cej.2013.06.074

Sriprapat, W., Suksabye, P., Areephak, S., Klantup, P., Waraha, A., Sawattan, A., et al. (2014). Uptake of Toluene and Ethylbenzene by Plants: Removal of Volatile Indoor Air Contaminants. Ecotoxicology Environ. Saf. 102 (1), 147-151. doi:10.1016/j.ecoenv.2014.01.032

Stapleton, E., and Ruiz-Rudolph, P. (2018). The Potential for Indoor Ultrafine Particle Reduction Using Vegetation under Laboratory Conditions. Indoor Built Environ. 27 (1), 70-83. doi:10.1177/1420326×16668388

Stelzer-Braid, S., Tovey, E. R., Willenborg, C. M., Toelle, B. G., Ampon, R., Garden, F. L., et al. (2016). Absence of Back to School Peaks in Human Rhinovirus Detections and Respiratory Symptoms in a Cohort of Children with Asthma. J. Med. Virol. 88 (4), 578-587. doi:10.1002/jmv.24371

Sturman, L. S., and Holmes, K. V. (1983). The Molecular Biology of Coronaviruses. Adv. Virus. Res. 28 (C), 35-112. doi:10.1016/s0065-3527(08)60721-6
Suwardi, A., Ooi, C. C., Daniel, D., Tan, C. K. I., LiLiang, H. Z., Liang, O. Y. Z., et al. (2021). The Efficacy of Plant-Based Ionizers in Removing Aerosol for COVID-19 Mitigation. Research 2021, 1-11. doi:10.34133/2021/2173642

Tai, W., He, L., Zhang, X., Pu, J., Voronin, D., Jiang, S., et al. (2020). Characterization of the Receptor-Binding Domain (RBD) of 2019 Novel Coronavirus: Implication for Development of RBD Protein as a Viral Attachment Inhibitor and Vaccine. Cell Mol Immunol 17 (6), 613-620. doi:10.1038/s41423-020-0400-4

Tang, J. W. (2009). The Effect of Environmental Parameters on the Survival of Airborne Infectious Agents. J. R. Soc. Interf. 6 (Suppl. 6), S737. doi:10.1098/ rsif.2009.0227.focus

Tikellis, C., and Thomas, M. C. (2012). Angiotensin-Converting Enzyme 2 (ACE2) Is a Key Modulator of the Renin Angiotensin System in Health and Disease. Int. J. Peptides 2012, 256294. doi:10.1155/2012/256294

Uddin, M., Mustafa, F., Rizvi, T. A., Tom, L., Al Suwaidi, H., Ahmed, H., et al. (2020). SARS-CoV-2/COVID-19: Viral Genomics, Epidemiology, Vaccines, and Therapeutic Interventions. Viruses 12 (5), 526. doi: $10.3390 / \mathrm{v} 12050526$

Uk Lee, B., Yermakov, M., and Grinshpun, S. A. (2004). Removal of Fine and Ultrafine Particles from Indoor Air Environments by the Unipolar Ion Emission. Atmos. Environ. 38 (29), 4815-4823. doi:10.1016/ j.atmosenv.2004.06.010

Ullah, H., Ullah, A., Gul, A., Mousavi, T., and Khan, M. W. (2020). Novel Coronavirus 2019 (COVID-19) Pandemic Outbreak: A Comprehensive Review of the Current Literature. Vacunas 22, 106. doi:10.1016/ j.vacun.2020.09.009

Vellingiri, B., Jayaramayya, K., Iyer, M., Narayanasamy, A., Govindasamy, V., Giridharan, B., et al. (2020). COVID-19: A Promising Cure for the Global Panic. Sci. Total Environ. 725, 138277. doi:10.1016/j.scitotenv.2020.138277

Walker, C. M., and Ko., G. (2007). Effect of Ultraviolet Germicidal Irradiation on Viral Aerosols. Environ. Sci. Technol. 41 (15), 5460-5465. doi:10.1021/ es070056u

Walls, A. C., ParkTortorici, Y.-J., Tortorici, M. A., Wall, A., McGuire, A. T., and Veesler, D. (2020). Structure, Function, and Antigenicity of the SARSCoV-2 Spike Glycoprotein. Cell 181 (2), 281-292.e6. doi:10.1016/ j.cell.2020.02.058

Wang, J., Tang, K., Feng, K., Li, X., Lv, W., Chen, K., et al. (2020). Impact of Temperature and Relative Humidity on the Transmission of COVID-19: A Modelling Study in China and the United States. BMJ Open 11, e043863. doi:10.1136/bmjopen-2020-043863

Wei, Z., Van Le, Q., Peng, W., Yang, Y., Yang, H., Gu, H., et al. (2021). A Review on Phytoremediation of Contaminants in Air, Water and Soil. J. Hazard. Mater. 403 (July 2020), 123658. doi:10.1016/j.jhazmat.2020.123658

Weidener, M., and Teixeira da Silva, J. (2006). Potential an Limitations of Ornamental Plants for Indoor-Air Purification. Floriculture, Ornamental Plant Biotechnol. 4, 54-63.

Wolverton, B., and Wolverton, J. (1993). Plants and Soil Microorganisms: Removal of Formaldehyde, Xylene, and Ammonia from the Indoor Environment. J. Miss. Acad. Sci. 38 (2), 11-15.

Wolverton, B., and Wolverton, J. D. (1996). Interior Plants: Their Influence on Airborne Microbes inside Energy-Efficient Buildings. J. Miss. Acad. Sci. 41 (2), 99-105.

Wolverton, B. C., Johnson, A., and Bounds, K. (1989). Interior Landscape Plants for Indoor Air Pollution Abatement. NASA, 57-71.

Yan, A., Wang, Y., Tan, S. N., Yusof, M. L. M., Ghosh, S., and Chen, Z. (2020). Phytoremediation: A Promising Approach for Revegetation of Heavy Metal-Polluted Land. Front. Plant Sci. 11 (April), 1-15. doi:10.3389/ fpls.2020.00359

Yang, H., Koo, T.-H., Hong, C.-Y., Choi, I.-G., Hong, J. E.-B., Choi, I. G., et al. (2012a). Analysis of the Effects of Essential Oils on Airborne Bacteria in a Customized Bio-Clean Room. Mol. Med. Rep. 6 (3), 651-656. doi:10.3892/ mmr.2012.972

Yang, W., Elankumaran, S., and Marr, L. C. (2012b). Relationship between Humidity and Influenza A Viability in Droplets and Implications for Influenza's Seasonality. PLoS ONE 7 (10), 1-8. doi:10.1371/ journal.pone.0046789

Zhang, W., Cao, S., Cao, S., Martin, J. L., Mueller, J. D., and Mansky L, M. (2015). Morphology and Ultrastructure of Retrovirus Particles. AIMS Biophys. 2 (3), 343-369. doi:10.3934/biophy.2015.3.343 
Zhou, B., Thao, T. T. N., Hoffmann, D., Taddeo, A., Ebert, N., Labroussaa, F., et al. (2021). SARS-CoV-2 Spike D614G Change Enhances Replication and Transmission. Nature 592 (7852), 122-127. doi:10.1038/s41586-02103361-1

Zhou, Y., Hou, Y., Shen, J., Huang, Y, Martin, W., and Cheng, F. (2020). NetworkBased Drug Repurposing for Novel Coronavirus 2019-NCoV/SARS-CoV-2. Cel Discov. 6 (1). doi:10.1038/s41421-020-0153-3

Zhu, N., Zhang, D., Wang, W., Li, X., Yang, B., Song, J., et al. (2020). A Novel Coronavirus from Patients with Pneumonia in China, 2019. N. Engl. J. Med. 382 (8), 727-733. doi:10.1056/nejmoa2001017
Conflict of Interest: The authors declare that the research was conducted in the absence of any commercial or financial relationships that could be construed as a potential conflict of interest.

Copyright (๑) 2021 El-Tanbouly, Hassan and El-Messeiry. This is an open-access article distributed under the terms of the Creative Commons Attribution License (CC BY). The use, distribution or reproduction in other forums is permitted, provided the original author(s) and the copyright owner(s) are credited and that the original publication in this journal is cited, in accordance with accepted academic practice. No use, distribution or reproduction is permitted which does not comply with these terms. 